\title{
Fred Maynard and the Australian Aboriginal Progressive Association (AAPA): One God, One Aim, One destiny
}

\author{
John Maynard
}

Opposition to the invasion of this country is not some new-found strength that Aboriginal people have suddenly discovered. It did not spring from the Mabo decision or the Native Title Act 1993, nor was its birth a result of the vibrant period of the 1960s, which culminated in the Aboriginal tent embassy in Canberra. The groundswell of Aboriginal resistance to domination has been ongoing since Cook and the Endeavour first appeared over the horizon. It did not cease when the last gunshot was heard on the frontier. Resistance has taken many forms since 1770 , from small encounters, to guerilla warfare, open warfare and the war of words. The formation of the first politically organised and united Aboriginal activist group, the Australian Aboriginal Progressive Association (AAPA) began in 1924 under the leadership of Charles Fredrick Maynard. ${ }^{1}$ This group proved a revelation and inspiration to Aboriginal people of their period and into the future. The AAPA saw, for the first time, Aborigines voicing their disapproval by holding street rallies, conducting meetings and conferences, utilising the power of the media through newspaper coverage, writing letters and petitions to Government and King George $\mathrm{V}$ about the injustice and inequality forced upon Aboriginal people. This form of resistance has now been ongoing for over seventy years, gaining in momentum and strength with each passing year. Until recently, little was known of the AAPA or its leader Fred Maynard. To appreciate the legacy of, and the momentum created by the AAPA, it is vitally important to examine not only the formation of the AAPA, the platform it took and the people involved, but why the AAPA was stopped.

The story of Fred Maynard and the Australian Aboriginal Progressive Association is one that holds special significance for me, as he was my grandfather. He sadly died eight years before my birth so I unfortunately never gained the opportunity of coming into contact with this remarkable Aboriginal patriot. In late 1993 I went to the Wollotuka Aboriginal Education Center at the University of Newcastle. My intention at that point was to ask advice on how best to go about gaining further information regarding my grandfather's activities during the 1920s. I received some good advice and also finished up enrolled in the Diploma of Aboriginal Studies, which I completed in 1995.

1. Broome 1982, p. 166. 
Throughout my studies I continued with my research centred on both my grandfather and the AAPA. In early 1996 I was fortunate to receive the Stanner Fellowship. The fellowship is awarded every second year to an indigenous scholar and is a very competitive and prized honour. The Fellowship offered me the opportunity to work in and research an area of Aboriginal history for possible publication. It provided me with the financial freedom over a four month period to travel in excess of 10,000 kilometres throughout New South Wales and Queensland, speaking to and recording many family members and people who had recollections of either the AAPA or my grandfather. This oral history was substantiated by extensive reading and researching archival material at the NSW State Archives, the Mitchell Library and many other less prominent libraries and historical societies. I received great support and encouragement from many notable historians like Dr Peter Read, Dr Heather Goodall and Jack and Jean Horner, who readily gave time and advice. This article is the result of those months of constant travel and work. It is important to all members of my family as it highlights the high levels of commitment and sacrifice that my grandfather made in battling to improve Aboriginal conditions at a most difficult time in Aboriginal history. Certainly the story of Fred Maynard and the Australian Aboriginal Progressive Association has been for a long period another missing chapter of Australian history. Its telling certainly reveals that the birth of an awakening of Aboriginal political consciousness was much earlier than it was, and still is, perceived to have been by a majority of people.

From the very outset the AAPA was to set a precedent for Aboriginal protest groups. Its aim was to improve the material conditions of Aboriginal people and end political oppression. ${ }^{2}$ Members of the AAPA were very vocal about the loss of Aboriginal reserve lands in New South Wales. From 1913 to 1927 Aboriginal reserve land in New South Wales fell from 26,000 acres to only 13,000 acres. ${ }^{3}$ Over 75 per cent of this land loss occurred on prime coastal land. ${ }^{4}$ Aboriginal people had successfully settled, cultivated, maintained and independently farmed this land virtually right up to the point when they were forcibly removed from their farms at gunpoint by the police. ${ }^{5}$ The AAPA opposition to this land theft was blunt and to the point. They had land as their prime requisite, demanding enough land for every Aboriginal family in the State in order to provide economic independence.

Their most scathing attack was directed at the NSW Aboriginal Protection Board. Even today the Protection Board is justifiably looked back on by Aboriginal people as a sinister government organisation, held in both fear and contempt. The AAPA insisted on the right of Aboriginal families to 'protect' their children from the 'Protection Board'. It was the Board's policy to remove Aboriginal children from their families. ${ }^{6}$ All-encompassing amendments to legislation concerning Aborigines implemented by the Board in 1915 were instrumental in Aboriginal children being classified as neglected and hence institutionalised, simply on the basis of their Aboriginality. ${ }^{7}$ Peter Read reports that

2. Grimshaw 1994, p. 281.

3. Goodall 1988, p. 6; see also Goodall 1996.

4. ibid.

5. ibid.

6. Read 1996a, p. 206; see also Read 1996b.

7. Grimshaw 1994, p. 290. 


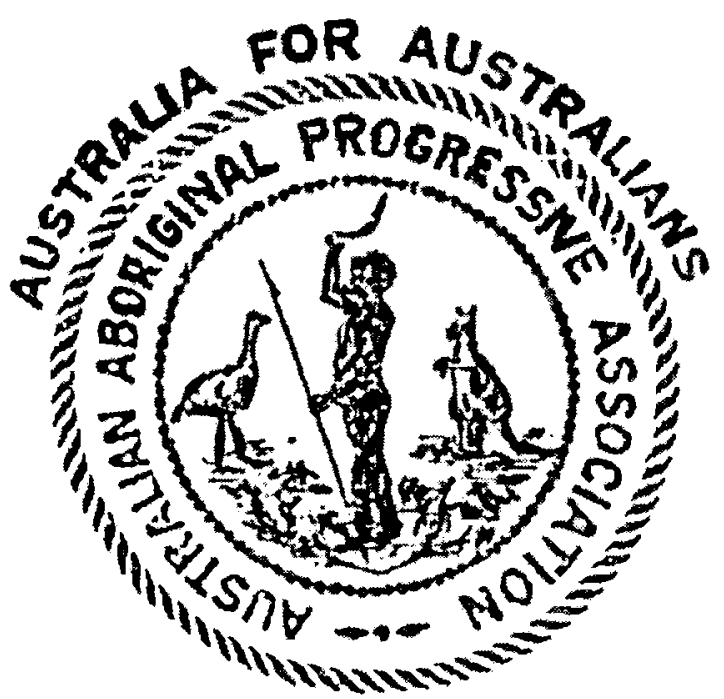

managers of reserves when filling out committal notices for the Board, simply wrote 'for being Aboriginal'. ${ }^{8}$ The practice of removal was condoned and sanctioned by the Board under the guise of the so-called 'apprenticeship scheme', which involved the taking of these children (a high percentage were girls) and relocating them in different parts of the State to be used and abused as child labourers for white farmers. ${ }^{9}$

The AAPA also made demands for Aborigines to be able to live in areas of significance to their various groups. They pioneered the call for Aborigines themselves to control administration and direction of Aboriginal affairs. The coverage of the AAPA's demands encompassed the entire spectrum of Aboriginal bitterness, focusing on both land rights and civil rights. As Goodall notes, the organisation was clearly saying 'We want rights over our own land, our own country', but as well they were saying they wanted access to full rights and privileges of citizenship. ${ }^{10}$ This was directed at every aspect of securing equal rights with other Australians. After all, Aboriginal people were being used and abused in the workforce, they were paying taxes, so why should they be denied access to public schooling, hospitals, swimming pools and the streets of the towns. ${ }^{11}$ However, the massive loss of reserve land and the way of life it had offered were the two catalysts which ignited the AAPA into existence. Each of the prominent members of the AAPA suffered and were affected by this land loss and the independent Aboriginal farmlands that it involved. ${ }^{12}$

AAPA president Fred Maynard was born at Hinton in the Hunter Valley on 4 July 1879. ${ }^{13}$ His uncle was Tom Phillips, one of the Aboriginal farmers who had settled and farmed St Claire reserve outside Singleton. This reserve had, in the first instance, been encroached upon by missionaries then taken over by the NSW Aboriginal Protection Board in 1916. By 1923 it was closed off to Aborigines altogether. ${ }^{14}$

Fred Maynard rose to prominence as a public speaker, voicing his disapproval at the suffering of Aboriginal people. Maynard proved to be a man of great sincerity, vision and compassion. He had the ability to inspire an audience and through his

8. Read 1982, pp. 5-7.

9. Kondek 1988, p. 175.

10. Goodall 1988, p. 6; see also Goodall, p. 1996.

11. ibid.

12. Goodall 1990, p. 22; see also Goodall 1996.

13. Oakenfall 1994, p. 672.

14. Goodall 1992, p. 22; see also Goodall 1996. 
speeches, his political views and general dissatisfaction with Aboriginal treatment was heard. This was viewed by the white authorities with some alarm, as they believed he was inciting revolt. It was because of his stance that he was denied the right to visit and speak on Aboriginal reserves. ${ }^{15}$ He was charismatic, dignified and eloquent and the major driving force behind the birth of the AAPA. ${ }^{16}$

Maynard formed the nucleus of the organisation around an impressive array of Aboriginal individuals. These included William and John Ridgeway, who had been fighting for land against white encroachment at Tea Gardens since the early years of the century, and only had only lost Forster in $1923^{\prime} .{ }^{17} \mathrm{~J}$. Johnstone was named vice president of the AAPA. He was from a family which had settled the Wingham reserve in 1882, only losing it to revocation in $1921 .{ }^{18}$ Johnstone's role in Aboriginal activism would continue over the ensuing decades and he also played a part in the later Aborigines Association headed by Bill Ferguson. James Linwood was another active member of the AAPA. He had been given approval to farm in 1883 and worked tirelessly to clear and cultivate 20 acres on the fertile Fattorini Islands in the Macleay area of northern NSW. ${ }^{19}$ By 1889 Linwood had three homes, two ploughs and one harrow, and his return on his maize crop of $£ 156.0 .8$ had seen him rise out of debt. ${ }^{20} \mathrm{He}$ was also to feel the anguish and disillusionment of being forced off his land when it was revoked in $1924 .{ }^{21}$ Linwood was to prove an accomplished speaker and it was he who addressed one of the AAPA's first public meetings, held in Kempsey in 1925, attracting a crowd of over 500 Kooris. ${ }^{22}$ Joe Anderson, along with his brothers, had worked St Josephs farm in the Burragorang valley: that land was also lost to them through revocation in $1924 .^{23}$ As a result, the family was forced to relocate to the Salt Pan Creek camp in Sydney. It was from the harshness of this injustice that he was enlisted and rallied to the cause of the AAPA. Joe was to become a prominent figure, and he started making speeches and demands for Aboriginal rights in and around the Sydney Markets and Domain during the 1920s. Jane Duren also rallied to the cause, having seen her people's land slowly encroached upon and swallowed up around Batemans Bay. She fought a strong, bitter and vocal campaign against such land loss. As a result she decided to align herself with the AAPA platform.

The popular memory of the independent NSW reserves was fresh in the minds of all of these people. ${ }^{24}$ So too, was the bitterness burnt and etched into their consciousness at the loss of those lands. This was overlaid by the new harsh and reduced reserves which were to prove more like concentration camps with their strict curfews and denied access to Aboriginal leaders like Fred Maynard. ${ }^{25}$ Confinement on these

15. Kondek 1988, p.175.

16. Kondek 1988, p.176.

17. Goodall 1990, p.23; see also Goodall 1996.

18. ibid.

19. Morris 1989, p. 93.

20. ibid.

21. Goodall 1990, p.23; see also Goodall 1996.

22. ibid.

23. ibid.

24. ibid.

25. Goodall 1990, p.1; see also Goodall 1996. 
reserves would prove to be a method by which the NSW Government sought to assimilate Aboriginal people and destroy the structure of their society and religion. Aboriginal people were forced off their land and incarcerated into an environment of control which stripped them not only of land, but also of their dignity and culture. The result was forced dependency which is still in evidence to this day. The managers of these reserves had enormous powers over resident Aboriginal people, including: the right to search Aborigines, their dwellings and belongings at any time; to confiscate their property, read their mail, order medical inspections, confine children to dormitories, expel Aborigines to other reserves and break up families. ${ }^{26}$

The senior members of the AAPA enlisted the support and sympathies of some notable white people. The NSW Aboriginal Protection Board caught wind that an organisation was beginning to blossom in December of 1923 when a white woman, Mrs. Elizabeth McKenzie-Hatton, contacted them putting forth a request to care for so-called 'incorrigible Aboriginal girls'. ${ }^{27}$ (The only reason they were classified as incorrigible was because they refused to take the abuse and ill treatment dealt to them and repeatedly absconded or defied their employer ${ }^{28}$ ). The proposed care put forward by Mrs McKenzie-Hatton revolved around a home being set up for these girls with funds hopefully to be provided by the Government. The proposal had been carefully planned by, and had full backing of the Aboriginal people connected with the AAPA. It was an Aboriginal controlled initiative that had the support of Aboriginal communities, who directed girls in need to the home. Sadly, however, the Protection Board stopped any hopes of funds being supplied for the proposal. Nevertheless, with or without funds, the home began operation at Homebush in Sydney in $1924 .{ }^{29}$ This home operated through 1924 and 1925 in direct opposition to the Protection Board and government controlled homes. The Protection Board was infuriated by this 'blatant' opposition to its authority and repeatedly directed the police to harass the home which was under constant surveillance, even going as far as to call in a Crown Solicitor who could find no legal loophole to have the home closed.

Mrs McKenzie-Hatton had come to NSW from Victoria prior to 1923 where she quickly came to the notice of Kooris in Sydney and the North Coast. ${ }^{30}$ She was especially concerned at the heartfelt loss of Aboriginal families for their children and, much to her credit, took it upon herself at personal cost, to travel the State in search of the stolen children that had been swept up in the so called 'apprenticeship scheme'. ${ }^{31}$

The members of the AAPA emerged in to full public view in February 1925, when the Association was officially launched. Mrs McKenzie-Hatton held the position of secretary. ${ }^{32}$ It is worth noting that all other office bearers were Aboriginal. Over the next six months, McKenzie-Hatton travelled extensively on the north coast spreading the news of the formation of the AAPA and developing contacts with Aboriginal communi-

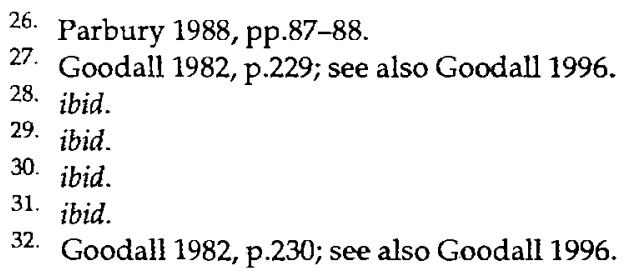


ties. The Protection Board, ever watchful and vigilant, refused her permission to visit reserves or stations. 'On one of these trips and with the co-operation of the Koori community at Nambucca Heads, McKenzie-Hatton removed an Aboriginal girl from the Protection Board's control on the reserve at Stuarts Island ${ }^{\prime} .{ }^{33}$ The Protection Board were at a loss as to what action to take. The response, however, from Aboriginal communities with the opening of the girls home at Homebush in the face of Protection Board antagonism and the removal of the girl at Nambucca Heads from the control of the Board signaled that these victories carried immense significance. The AAPA had struck a chord with the people: at last some of their own were playing the white authorities at their own game and hitting back at what had seemed an insurmountable wall of control.

News of the AAPA now spread like a brush fire through Aboriginal communities from as far south as Batemans Bay to Lismore in the north and west to places like Angledool Station. Fred Maynard operated the Association's central office from Addisons Hall, 460 Crown Street, Sydney, but he was prompted by the response to make trips to the north coast. Maynard said he was amazed by the enthusiastic response that the AAPA were generating: by August it claimed eleven branches and a membership which had expanded to numbers in excess of five hundred. ${ }^{34}$

Besides Mrs. McKenzie-Hatton, the AAPA had the aid of another white person who supported the Aboriginal stance, Mr J.J. Maloney. Mrs McKenzie-Hatton had instigated a campaign of writing letters to the press. However, few were ever published. One exception to this rule was the Newcastle newspaper the Voice of the North. The editor, Maloney, who was a staunch nationalist, was impressed by Aboriginal leaders like Maynard and Lacy and printed whatever they had to say. Maloney, to his credit, had been penning editorials on the need to save the Aborigines as early as 1922. At the time, this was a most unusual occurrence as few white people questioned the 'doomed race' hypothesis that was expounded in newspaper articles of the time by high profile politicians and academics. For example, on 30 January 1920, Premier Sir Joseph Caruthers, in an interview in the Macleay Argus stated that the Australian Aborigine will soon be but a memory to those who people this continent' ${ }^{35}$ American anthropologist, Dr William Lloyd Warner was another exponent of the 'doomed race' theory of the period, and when on a visit to Australia in 1927, he suggested to a reporter of the Telegraph (20 October 1927) 'that it was tragic to think that the happiest people in the world should be doomed to extinction', but such was his conviction on the issue, he went on to say, 'the fate of the Australian blacks will be that of the American Indian-they will vanish from the face of the earth. ${ }^{36}$ Three days later, in another article in the Telegraph (23 October 1927), the writer suggested that, 'now that the Australian Aborigines are dying out...[i]t has been suggested that the Australian artist, B.E. Minns be commissioned by the Federal Government to supply some artistic memorials of our passing black brothers' ${ }^{37}$

This was the stigma Aboriginal people and the AAPA confronted as a result of the mentality of the period. The AAPA, due to its success, was now perceived by the Pro-

33. Goodall 1982, p.231; see also Goodall 1996.

34. ibid.

35. Macleay Argus 30/1/1920.

36. Telegraph 20/10/1927.

37. Telegraph 23/10/1927. 
tection Board as a serious threat and the Board initiated ways of undermining and blocking its progress. They directed the majority of their attacks at Fred Maynard. At a meeting in Newcastle in late 1925, Maynard addressed a large crowd where he further emphasised the AAPA's stand that all Aborigines receive freehold land, and initiated a call for the cessation of the removal of Aboriginal children by the Protection Board. He also called for a royal commission into Aboriginal affairs and wanted the unconditional and complete abolition of the Protection Board. Maynard stressed that the board had outlived its usefulness and that Aborigines required a new system of administration... without the foolish patronage which affects to regard them as children'. ${ }^{38}$

After this attack by Maynard, the Protection Board became more enraged and intensified their own attacks against him personally. First, they tried to discredit him by claiming he was not Aboriginal at all, but rather an American Negro or South African 'Black'. The facts were that Maynard's roots lay with the Worimi people of Port Stephens. On the registered birth certificate of his aunt Caroline, on 31 May, 1859 his great-grandmother Mary is noted as an 'Aboriginal woman born at Port Stephens (who can read)'. Mary had married Jean Phillipe (anglicised as Phillips) in 1846. Phillipe had arrived in Australia from the Isle of France (Mauritius). Some say that he may have jumped ship whilst in Australia.

When this approach to discredit Maynard failed due to the strength of his strong family ties with his people in both Wonnarua and Worimi country, the Protection Board then tried to implicate him in a sexual scandal. ${ }^{39}$ They attempted to tarnish Maynard's name by making public a letter he had written to a fifteen year old Aboriginal girl who had been taken from her family at the camp at Dunembrol property by the Protection Board and put into the apprenticeship scheme. She was placed on a property remote from her family where she was subjected to rape by her white employer. She was sent to Sydney to have her child who died soon after birth. Incredibly, the Protection Board then sent her back to the same place of employment and abuse at Angledool Station. ${ }^{40}$ Through the extensive Aboriginal community network, news of this girl's plight reached the AAPA in October $1927 .{ }^{41}$ Maynard wrote to her offering help in bringing the man responsible to justice. He asked the girl for particulars of the assaults, which would be necessary in proving paternity. It seems it was this aspect of Maynard's letter, as much as his criticism of the Protection Board, that the Board felt would tarnish and discredit Maynard's reputation. Quite the contrary happened. Once the Board were forced to publish the full contents of Maynard's letter, and, rather than diminishing him, the contents actually enhanced his already imposing reputation. In the letter, Maynard savagely attacked the Protection Board for affording no protection for Aboriginal girls whatsoever:

...These white robbers of our women's virtue, who take our girls down and laugh to scorn yet escape their obligations every time. The Act and the Board it empowered insulted and degraded all Aboriginal people, and it aimed to exterminate the noble and ancient race of Australia. These so-called civilised methods of rule,

38. Maynard 1925, p.5.

39. Kondek 1988, p.176.

40. Goodall 1982, p.246.

41. ibid. 
under the christianised ideals so they claim, of civilising our people under the pretence of 'love' were nothing more than downright hypocrisy and stink of the Belgian Congo. These Tyrannous methods have to be stopped. We are not going to be insulted any longer than it will take to wipe the Act off the Statute book. That's what our Association stands for: liberty, freedom, the right to function and act in our own interest, as right thinking citizens, not as non-intelligents devoid of all reason. That is how we are placed under the law of the Statute book. Anything is good enough, a blanket, a pinch of tea and sugar, anything thrown at us. Are we going to stand for these things any longer? Certainly not! Away with the damnable insulting methods, which are degrading. Give us a hand; stand by your native Aboriginal officers and fight for liberty and freedom for yourself and for your children... ${ }^{42}$

Unfortunately for Maynard, this letter had been intercepted and opened by the manager of the property who sent it on to the Protection Board. Even so, it is highly likely that the girl would have been too frightened or threatened to allow him to take legal action on her behalf. The Protection Board was further concerned by this challenge to their authority. When the AAPA applied for official registration of the organisation as a company, the Board tried unsuccessfully to block the registration. The Board referred to the stereotypical view of Aboriginal people, stating that the AAPA, excepting Mrs McKenzie-Hatton, were Aborigines 'incompetent and of poor character' which the Board would in due course expose and make evidence against them available to the Registrar General. ${ }^{43}$

Jane Duren pushed notice of Aboriginal discontent to prominence by sending on 14 June 1926 a letter to King George V in which she stated the complete dissatisfaction in government that Aboriginal people felt. Her letter pointed out the utter unfairness and hypocrisy of a system that went as far as to exclude Aboriginal children from public schooling. 44

The year of 1927 proved to be the most active one for the AAPA and its members. They continued their vehement attacks on the Protection Board and continued to bombard the press and government with letters, petitions and demands. They conducted their third annual general meeting and the resolutions endorsed were to form the basis of a petition that was sent to the then Premier of NSW, Mr Jack Lang. Their demands, as from the outset nearly four years earlier, had not wavered:

...Restore to us that share of our country of which we should never have been deprived... ${ }^{45}$

The petition also insisted that Aborigines who were incapable of working the land were only in that condition due to neglect and because of government policies, which had endorsed oppression and prejudice. It went on to demand that it was the government's responsibility to provide and care for these people. In the petition the AAPA also reiterated their stance on the demand for the cessation of the Protection Board's policy of taking Aboriginal children from their families. They wanted the Board scrapped completely and replaced by an Aboriginal administrative organisation controlled and

42. Maynard to K-B 1927.

43. Goodall 1982, p.236; see also Goodall 1996.

44. Goodall 1982, p.237; see also Fletcher 1989

45. Goodall 1982, p.241; see also Goodall 1996. 
operated by educated Aboriginals. They went on to stress that Aborigines be afforded the full privileges of citizenship. ${ }^{46}$ The Protection Board's response to the petition was predictable and took their usual racist stance by categorising Aboriginal people as incompetent and incapable of managing their own affairs. They went so far in their opposition to Aboriginal demands for land as to reply to the government:

...The Board knowing the nature of the Aboriginal is of the opinion that in most cases the property would be quickly disposed of for more liquid assets... ${ }^{47}$

The Protection Board went on with their attack by voicing their opinion of Fred Maynard:

...He was a man of illogical views who, in the Board's opinion, was more likely to disturb the Aborigines than improve their conditions. ${ }^{48}$

When knowledge of the Protection Board's attack reached Fred Maynard, his response to this open display of racist prejudice and aggression inspired him to pen one of the most eloquent and powerful statements ever written by an Aboriginal activist:

I wish to make it perfectly clear on behalf of our people, that we accept no condition of inferiority as compared with European people. Two distinct civilisations are represented by the respective races... That the European people by the arts of war destroyed our more ancient civilisation is freely admitted, and that by their vices and diseases our people have been decimated is also patent. But neither of these facts are evidence of superiority. Quite the contrary is the case. Furthermore, I may refer in passing, to the fact that your present scheme of old age pensions was obtained from our more ancient code, as likewise your child endowment scheme and widows pensions. Our divorce laws may yet find a place on the Statute Book. The members of the Board [the AAPA] have also noticed the strenuous efforts of the trade union leaders to attain the conditions which existed in our country at the time of the invasion by Europeans-the men only worked when necessary, we called no man 'master' and we had no king. We are therefore, striving to obtain full recognition of our citizen rights on terms of absolute equality with all other people in our land. The request made by this Association for sufficient land for each eligible family is justly based. The Australian people are the original owners of this land and have a prior right over all other people in this respect. Our request to supervise our own affairs is no innovation. The Catholic people in our country possess the right to control their own schools and homes, and take pride in the fact that they possess this privilege. The Chinese, Greeks, Jews and Lutherans are similarly favoured and our people are entitled to precisely the same conditions. ${ }^{49}$

Maynard categorically denounced the claims made by the Protection Board that it was adequately providing for the aged and indigent Aborigines, referring to the Board's reference to the generosity of ration and blanket as a 'sneer' ${ }^{50} \mathrm{He}$ also attacked the Board's integrity by calling its refusal to agree to a royal commission, as proposed by the AAPA, as proof that the Board was afraid to face the consequences and truths such an inquiry would uncover. ${ }^{51}$ The Protection Board replied again with only an

46. Goodall 1982, p.242; see also Goodall 1996.

47. Goodall 1982, p.247; see also Goodall 1996.

48. ibid.

49. Maynard 1927.

50. Goodall 1982, p.244; see also Goodall 1996. 
expanded version of its earlier letter. They completely avoided the crucial issues and a carefully worded statement did not disguise the fact that the Board did assume Aboriginal people were 'inferior':

The Board cannot concern itself with the controversy regarding the inferiority or otherwise of the Australian Aboriginal race as compared with Europeans, its duty being to ensure that the remnants of that race now living within this State receive benevolent protection and every reasonable opportunity to improve its condition...52

The AAPA disappeared from mainstream public view after 1927. As yet there has been no concrete explanation uncovered for this apparent break up and disintegration of the AAPA's organisational and network structures. ${ }^{53}$ There are three main ingredients that were probably instrumental in the AAPA's demise. The first was obviously the onset of the Depression, which had a major bearing on the operation of the AAPA. Money would have been a major concern to the group. Maynard's children say that work days for their father on the wharf became few and far between. A more disturbing scenario was brought to light by Uralla elder, Mr Reuben Kelly. In interviews he stated that 'Fred Maynard was a great man, the genuine article, but he could not make the people understand'. Reuben said 'You could see it in his eyes, he suffered for the people'. Reuben was adamant that Fred Maynard was undermined from within his own group. Reuben concluded 'our people are too often bought and seduced by promises and accept the crumbs and carrots dangled before them' ${ }^{54}$ There may be some evidence of Reuben's view in a report in the Sydney Morning Herald (15 November 1927). The report described a meeting at the Chapter House of St. Andrews Cathedral, Sydney between the Bishop Coadjutor of Sydney, Revd D'Arcy Irvine and the chairman of the Australian Board of Missions the most Reverend J.S. Needham and seven Aborigines of the AAPA. The report said that the 'natives' sought the opportunity of stating their claims for racial equality with whites and other concessions. The report went on to say that 'for the most part, the President of the "natives" Progressive Association, Mr. F. G. Maynard, a self educated Aboriginal acted as spokesperson, although associates punctuated his remarks with interjections ${ }^{\prime}{ }^{55}$ This article may support a suggestion of internal differences inside the AAPA structure.

However, the major reason for the AAPA's breakup was without doubt based in police and Protection Board harassment. The AAPA conducted three annual conferences before being forced out of existence by police acting on behalf of the Protection Board. ${ }^{56}$ The organisation's demise served as a caution to William Ferguson, who later founded a separate organisation with an almost identical title-the Aborigines Progressive Association. ${ }^{57}$ This suggestion can be substantiated by a statement by Bill Ferguson to Charles Leon, made a decade after the AAPA ceased. When Leon pointed out the existence of the earlier AAPA organisation, Ferguson replied: 'Yes I've heard of them,

51. Goodall 1982, p.245.

52. ibid.

53. Goodall 1982, p.249.

54. Maynard 1996 interview with Reuben Kelly.

55. Sydney Morning Herald 15 November 1927.

56. Howie-Willis 1994, p.75.

57. ibid. 
they held three annual conferences but they were hounded by the police acting for the Board' ${ }^{58}$

One can arguably conclude that the Protection Board brought a sinister and increasingly hostile approach to bear on the AAPA. Members of the Maynard family, in reflections on their early childhood, all agree that threats were made against their father especially in relation to his family. ${ }^{59}$ It was a case of stop the political agitation, or suffer the consequences. Maynard's personal position with a young family was obviously precarious. Nevertheless, whether Maynard would have pressed on publicly with the fight remains unanswered. Whilst working in the early 1930 s in his capacity as a wharf labourer in Sydney a large container fell from a crane and struck him. He was seriously injured and spent nearly twelve months in hospital, one leg broken in six places. His health was further complicated by the fact that whilst in hospital he developed sugar diabetes, and his body was covered in sores from being confined to bed for so long. Maynard, a big powerful man, eventually was able to leave hospital, but his health had been seriously impaired. Eventually he contracted gangrene and had a leg amputated. He died on 9 September 1946.

It is feasible to assume that the Protection Board, with the apparent demise of the AAPA, assumed that all Aboriginal confrontation would now cease. The Board sought to stop the source of Aboriginal protest by silencing the AAPA, but the ground swell had begun and could not be stopped. The seeds were sown and would come to full fruition once again in the late 1960s and early 1970s, and continue to this day. It may be difficult to imagine or comprehend the opposition this pioneer group faced seventy years ago and to understand its considerable impact. This paper springs from the desire to observe and acknowledge the pain and suffering felt by our Aboriginal forebears in their resistance to white domination and to recognise their important contribution to our lives today. These people were brave enough to stand up and speak out in a time when it was not socially acceptable or safe to do so. Aboriginal Australians must draw strength and capitalise on their predecessor's achievements until justice and equality prevail for all Aboriginal Australians.

Certainly the story of my grandfather and the AAPA is one of triumph and courage. From the ashes of what many believed had perished have risen the buds of an Aboriginal movement that continues to this day.

There are still many unanswered questions and some mysteries surrounding both Fred Maynard and the AAPA. What of his young life and family background? There are accounts of him as a young man having travelled widely in a variety of jobs, working as a timber-getter on the north coast, a drover, a gold prospector with his own horse team in the Kimberleys and Flinders Ranges, a photographer and nurseryman with his own shop in Sydney. ${ }^{60}$ There are also long periods when knowledge of his whereabouts and actions is obscure or missing. Will conclusive evidence come to light to resolve the question of the demise of the AAPA? Finally, what measure of hardship did he endure or

58. Horner 1994, p.26.

59. Maynard (1996) interviews with Shirly Maynard, Mary Kondek, David Maynard and Mervyn Maynard.

60. Maynard (1996) interviews with Shirly Maynard, Mary Kondek, David Maynard and Mervyn Maynard. 
witness that inspired him to rise up and speak out so strongly and eloquently against the atrocities leveled at Aboriginal people? I sincerely hope to resolve many of these issues with further research.

John Maynard has a Diploma in Aboriginal Studies from the University of Newcastle. He was the Stanner Fellow for 1996. This Fellowship is sponsored by the Research School of Pacific Studies and is administered by the Board of 'Aboriginal History', and is tenurable at the Australian National University in Canberra. This article was written as part of the Fellowship. John Maynard has been Research Assistant at Wollotuka, the Aboriginal and Torres Strait Islander Education Unit, University of Newcastle, and Research Officer in Aboriginal and Islander Health within the Faculty of Medicine and Health Science at the University of Newcastle, and was a Visiting History Fellow at the Australian National University. He is now Associate Lecturer with the Wollotuka Centre, University of Newcastle.

\section{References}

Broome, R. 1982, Aboriginal Australians-Black Response to White Dominance 1788-1980, Sydney.

Fletcher, J.J. 1989, Documents in the history of Aboriginal Education in New South Wales, Marrickville

Goodall, H. 1982, A History of Aboriginal Communities in NSW 1909-1939, Ph.D thesis, University of Sydney, N.S.W.

Goodall, H. 1988, 'Aboriginal calls for justice-Learning from history', Aboriginal Law Bulletin, vol. 2, no. 33, pp. 4-6.

Goodall, H. 1990, 'Land in our own country: the Aboriginal land rights movement in south eastern Australia 1860 to 1914', Aboriginal History, vol. 14, numbers. 1-2, pp. 1-24.

Goodall, H. 1996, Invasion to Embassy-Land in Aboriginal Politics in NSW, $1770-1972$, St Leonards.

Grimshaw, M. et al. (eds) 1994, Creating a Nation 1788 to 1990, Melbourne.

Horner, J. 1994, Vote for Ferguson for Aboriginal Freedom, Brookvale, N.S.W.

Howie-Willis, I. 1994, 'Australian Aboriginal Progressive Association' in The Encyclopedia of Aboriginal Australia vol. 1, p. 75, Canberra.

Kondek, M. 1988, 'Vision of Justice for Aborigines' in Two hundred Unsung Heroes and Heroines of Australia, ed. W. Marshall-Stoneking and S. Baldwin, Victoria.

Macleay Argus, January 1920.

Maynard, F. 1925, Voice of the North, 10 November 1925, p.5.

Maynard, F. 1927a, Letter to the Premier, NSW Premiers Department Correspondence Files, A27/915.

Maynard, F. 1927b, Letter to Aboriginal girl, NSW Premiers Department Correspondence Files, A27/915.

Maynard, J. 1996, Oral interviews: conducted with R. Kelly, S. Maynard, D. Maynard, M. Kondek \& M. Maynard at Uralla, Central Coast, Mudgee, Hervey Bay \& Newcastle.

Morris. B. 1989, Domesticating Resistance: the Dhan-Gadi Aborigines and the Australian State, Oxford. 
Oakenfall, C. 1994 'Maynard. F' in The Encyclopedia of Aboriginal Australia, vol. 2, pg 672673, Canberra.

Parbury, N. 1988, Survival:A History of Aboriginal Life in NSW, Sydney.

Read, P. 1996a, A Rape of the Soul so Profound: some reflections on the dispersal policy in New South Wales, in 'Terrible Hard Biscuits' ed. by Chapman,V \& Read, P., St Leonards.

Read, P. 1996b, Human Rights and Equal Opportunities Commission (HREOC), Canberra.

Read, P. 1982, The Stolen Generations, Occasional paper No.1 Ministry of Aboriginal Affairs, Sydney

Sydney Morning Herald, November 1927.

Telegraph, October 1927. 